\title{
Analyzing Inventory Investment
}

INVENTORIES HAVE PLAYED A CRUCIAL ROLE in U.S. business cycles, for their perverse behavior has acted to magnify rather than dampen cyclical swings in demand. Indeed, fluctuations in inventory accumulation accounted on the average for 75 percent of the decline in real gross national product (GNP) experienced in the four recessions between 1948 and 1961. In addition, the erratic short-term behavior of inventory accumulationtypically representing half of the variation in quarterly GNP growthcreates a severe forecasting problem.

The topic is of current interest for two reasons. First, although a reduced rate of inventory accumulation contributed to the slowdown in the first half of 1970, the magnitude of the swing in inventory investment has been modest by comparison with those in similar postwar periods. Thus current developments stand in sharp contrast with experience as recent as 1966, when the annual rate of inventory accumulation reached $\$ 18.6$ billion in the fourth quarter with a major reversal down to $\$ 4.4$ billion by the second quarter of $1967 .{ }^{1}$ Do the two periods differ because the current slackening in sales was anticipated to an extent that allowed production to adjust smoothly? Or must alternative explanations be sought for the current stability of inventory investment?

Second, just as inventories have had a major influence during the contractionary phase of past cycles, they have been an important source of

1. For an analysis of that experience, see Barry Bosworth, "Current Inventory-Sales Relationships," Brookings Papers on Economic Activity (1:1970), pp. 134-39. 
expansion during the initial stages of recovery-accounting for an average of 40 percent of the growth in real GNP in the first two quarters following the trough. Such historical experience has led some observers to expect a similar recovery in late 1970 or in 1971 . Yet an analysis in terms of a typical "inventory cycle" is not applicable to the current situation simply because the 1969-70 economic slowdown has not been associated with a major inventory decumulation.

Another element in the near-term outlook for inventory investment is the current decline in defense procurement, which will be accompanied by a decline in inventories of defense industries. The importance of defense in the overall inventory outlook is significant, but not so overwhelming as a casual look at the period of defense buildup might suggest. The rapid expansion of defense orders and outlays in 1966 did coincide in time with the major overall inventory buildup during that period; and some of the inventory investment reflected a desire to fill the production pipeline in the defense industry with raw materials and goods-in-process. But analysis of that period indicates that only a minor fraction of the total inventory accumulation came in response to the defense buildup.

\section{Concepts and Data}

Inventory investment is dominated normally by the short-run adjustment of stocks to a relatively accurately known longer-term path. Variations in the long-run stock have only infrequently constituted a major forecasting problem, since the ratio of the inventory stock to sales has been highly stable over periods of two to five years, after allowance for a modest secular downtrend. On the other hand, forecasting the short-run changes in stocks around this path poses serious problems, for they are highly volatile. In part this volatility is accounted for by a more rapid adjustment of actual to desired stocks for inventories than for homes, plant and equipment, or even consumer durables. But the forecasting problem is complicated further because unanticipated sales changes must result in equal changes in stocks in the opposite direction, to the extent that the surprises are not immediately matched by expanded or curtailed production.

The interpretation of short-run inventory movements is further complicated by the fact that estimates of inventory accumulation that enter the national accounts are subject to more severe statistical problems than those of any other demand category. Since the stock estimates are made 
at a point in time rather than as an average of several periods, the measurement error is likely to be greater than that for corresponding estimates of flows. In addition, for the aggregate economy, inventories exhibit a "float" problem similar to that of trade debt and the money supply in the monetary sector. Unknown quantities of goods are continuously in transit between business establishments, and there is little reason to expect this flow to be much more stable than the mail float component of the money supply. But unlike money, inventory estimates have no control total and must be calculated as the sum of individual firm reports. Finally, the national accounts data measure changes in the volume of inventories by adjusting the book value data for price changes - through the inventory valuation adjustment - and this introduces another volatile source of potential error.

While these conceptual and statistical problems make a high degree of accuracy more than usually difficult to obtain, nothing less will suffice if a meaningful evaluation of the economic impact of inventory investment is to be made. A 1 percent error in forecasting nonfarm inventories does not seem large if viewed as less than half of a single day's sales. Yet this would imply about a $\$ 6.8$ billion error (annual rate) in the quarterly estimates of GNP in the national accounts.

The following section presents a set of equations that provide a framework for examining recent inventory developments. The results emphasize the need for at least some disaggregation of inventory investment as a means of isolating important differences in inventory behavior among major economic sectors. They also provide a partial list of the major determinants of inventory accumulation that must be considered in predicting future developments.

Next, these empirical relationships are used to examine the reasons for the relative stability of recent inventory investment compared with historical experience, especially with the $1966-67$ period. The paper concludes by exploring the importance of special factors, particularly defense orders, for inventory investment in the near future.

\section{Statistical Findings}

Any detailed examination of inventory investment requires at the minimum a distinction among three sectors: nondurables (trade and manufacturing combined), durable trade, and durable manufacturing. Although disaggregation creates some additional problems of measurement, there 
are important differences in inventory behavior among these sectors that deserve recognition. It is necessary to distinguish between production in response to known orders-production to order-and production in anticipation of future demand-production to stock. In the latter case, inventory planning is complicated by errors in sales forecasts that lead to involuntary inventory changes. In the former case, which characterizes inventories in durable manufacturing, sales surprises are less important. Rather, inventory movements are dominated by goods-in-process and require an alternative explanation.

Inventory investment of producers to stock can be viewed as an attempt to smooth out production by holding stock as a buffer against sudden changes in sales. This type of behavior can be described formally by specifying a desired inventory-sales relationship, a production rule, and the determinants of expected sales. ${ }^{2}$ Desired inventories at the end of a period $V_{t}^{*}$ may be taken to be a linear function of expected sales during the period $S_{t}^{e}$ with an intercept (positive or negative) denoted as $a$ and a slope-coefficient (positive) denoted as $b$. Then:

$$
V_{t}^{*}=a+b S_{t}^{e}
$$

Production $P_{t}$ is planned to equal expected sales plus a proportion $c$ of the difference between desired and actual stocks at the end of the previous period:

$$
P_{t}=S_{t}^{e}+c\left(V_{t}^{*}-V_{t-1}\right) .
$$

Then actual inventory accumulation in the period $\left(V_{t}-V_{t-1}\right)$, which will be the difference between production and actual sales during the period $S_{t}$, will display the familiar stock-adjustment form,

$$
V_{t}-V_{t-1}=c a+c b S_{t}^{e}-c V_{t-1}+\left(S_{t}^{e}-S_{t}\right) .
$$

Thus, in the buffer stock model, inventory accumulation is composed of an anticipated component, which is related to the speed with which production is adjusted to sales changes, and an unanticipated component resulting

2. For a more detailed presentation of this theory, see Lloyd A. Metzler, "The Nature and Stability of Inventory Cycles," Review of Economic Statistics, Vol. 23 (August 1941), pp. 113-29; Michael C. Lovell, "The Contribution of Inventory Investment to Cyclical Reversals in Economic Activity," in Inventory Fluctuations and Economic Stabilization, Hearings before the Subcommittee on Economic Stabilization, Automation, and Energy Resources of the Joint Economic Committee, 87 Cong. 2 sess. (1962), pp. 245-73; and Charles Holt and others, Planning Production, Inventories, and Work Force (PrenticeHall, 1960). 
from errors in the sales forecast. In the absence of appropriate sales forecasts, current and lagged sales are introduced into the equation and allowed to serve as a proxy for expected sales.

Table 1 presents the coefficients of a set of representative inventory equations for the major sectors, generally based on quarterly estimates of constant-dollar inventory stock from the Office of Business Economics for the period 1953-69.

\section{DURABLE TRADE}

The buffer stock model is most directly applicable to the durable trade sector. The greater cyclical sensitivity of durable goods sales, together with a higher inventory-sales ratio, results in more pronounced cyclical inventory movements than appear for nondurables.

The changing timing of introduction of new models and numerous automobile and steel strikes create difficulties in accounting for durable trade within a more aggregative framework. Some of these problems are reduced by eliminating the 1959 steel strike and the more severe auto strikes from the data sample. Nevertheless, the equation embraces several periods, such as the first quarter of 1961, when sudden movements in inventories of auto dealers cause substantial errors in predicting the total. The equation also noticeably understates inventory accumulation in durable trade in late 1958 and throughout 1966.

The statistical results show a potent negative impact of existing stocks on inventory investment. They also suggest that, either because forecasts of sales are quite accurate or because adjustments of stocks are rapid, a higher level of sales actually raises inventory investment within the current quarter. But a larger part of the resulting addition to stocks takes place in the next quarter.

\section{NONDURABLES}

Because sales of nondurables are relatively insensitive to cyclical influences, and because these goods are characterized by relatively low inventorysales ratios, inventory investment in this sector makes little contribution to major shifts in production. In fact, the variance of inventory investment is only slightly larger than the expected sampling variability of the basic surveys of reporting firms. A large proportion of the existing variance 
Table 1. Coefficients from Inventory Investment Equations, by Sector, 1953-69

\begin{tabular}{|c|c|c|c|c|c|}
\hline \multirow[b]{2}{*}{$\begin{array}{l}\text { Independent } \\
\text { variable }\end{array}$} & \multicolumn{5}{|c|}{ Equation } \\
\hline & $\begin{array}{c}\text { (1) } \\
\text { Durable } \\
\text { trade }\end{array}$ & $\begin{array}{c}\text { (2) } \\
\text { Non- } \\
\text { durables }\end{array}$ & $\begin{array}{l}\text { (3) } \\
\text { Equipment } \\
\text { and } \\
\text { defense }\end{array}$ & $\begin{array}{l}\text { (4) } \\
\text { Durable } \\
\text { manufac- } \\
\text { turinga }\end{array}$ & $\begin{array}{c}\text { (5) } \\
\text { Durable } \\
\text { manufac- } \\
\text { turing }\end{array}$ \\
\hline Lagged stock & $\begin{array}{r}-0.330 \\
(7.2)\end{array}$ & $\begin{array}{r}-0.192 \\
(4.5)\end{array}$ & $\begin{array}{r}-0.061 \\
(1.8)\end{array}$ & $\begin{array}{r}-0.160 \\
(6.7)\end{array}$ & $\begin{array}{r}-0.171 \\
(6.3)\end{array}$ \\
\hline Current sales & $\begin{array}{r}0.110^{\mathrm{b}} \\
(1.5)\end{array}$ & $\begin{array}{r}-0.142 \\
(1.8)\end{array}$ & $\begin{array}{r}-0.017 \\
(0.6)\end{array}$ & $\begin{array}{r}0.057 \\
(2.4)\end{array}$ & $\begin{array}{r}0.102 \\
(2.7)\end{array}$ \\
\hline Lagged sales & $\begin{array}{r}0.262 \\
(2.8)\end{array}$ & $\begin{array}{r}0.265 \\
(3.3)\end{array}$ & $\cdots$ & $\begin{array}{r}-0.038 \\
(1.5)\end{array}$ & $\begin{array}{r}-0.026 \\
(0.8)\end{array}$ \\
\hline Buying policy ${ }^{\circ}$ & $\ldots$ & $\begin{array}{c}0.053 \\
(4.6)\end{array}$ & $\begin{array}{r}0.138 \\
(5.8)\end{array}$ & $\cdots$ & $\cdots$ \\
\hline $\begin{array}{l}\text { Percent change in } \\
\text { farm prices }\end{array}$ & $\cdots$ & $\begin{array}{r}-0.090 \\
(4.0)\end{array}$ & $\cdots$ & $\cdots$ & $\cdots$ \\
\hline Change in orders & $\cdots$ & $\ldots$ & $\begin{array}{r}0.426^{\circ} \\
(3.7)\end{array}$ & $\cdots$ & $\begin{array}{l}1.51^{f} \\
(3.5)\end{array}$ \\
\hline $\begin{array}{l}\text { Capacity utilization } \\
\text { times change in orders }\end{array}$ & $\cdots$ & $\cdots$ & $\cdots$ & $\cdots$ & $\begin{array}{r}-1.88^{8} \\
(3.1)\end{array}$ \\
\hline $\begin{array}{l}\text { Predicted inventory } \\
\text { change of equipment } \\
\text { and defense }\end{array}$ & $\cdots$ & $\cdots$ & $\cdots$ & $\begin{array}{l}1.83 \\
(7.1)\end{array}$ & $\begin{array}{l}1.08 \\
(3.4)\end{array}$ \\
\hline Time & $\cdots$ & $\begin{array}{r}0.154 \\
(3.5)\end{array}$ & $\cdots$ & $\begin{array}{r}0.087 \\
(3.4)\end{array}$ & $\begin{array}{r}0.044 \\
(1.8)\end{array}$ \\
\hline Constant & $\begin{array}{l}5.84 \\
(5.7)\end{array}$ & $\begin{array}{l}7.67 \\
(3.2)\end{array}$ & $\begin{array}{r}-0.109 \\
(0.5)\end{array}$ & $\begin{array}{l}7.48 \\
(3.8)\end{array}$ & $\begin{array}{l}2.83 \\
(1.3)\end{array}$ \\
\hline$R^{2}$ & 0.56 & 0.58 & 0.82 & 0.84 & 0.88 \\
\hline Standard error of estimate & 0.96 & 0.98 & 0.63 & 0.96 & 0.85 \\
\hline
\end{tabular}

Source: Based on constant-dollar inventory data for 1953-69 from U.S. Department of Commerce, Office of Business Economics.

Note: The flow data are quarterly, seasonally adjusted at annual rates. Those for equipment and defense are in billions of current dollars. All others are in billions of 1958 dollars. Stocks are expressed at four times actual level. The equations are based on ordinary least squares estimates; it was found that corrections for simultaneous equation bias and autocorrelation did not materially affect the coefficients. The numbers in parentheses are $t$ ratios. The overall standard error is estimated at $\$ 1.7$ billion.

a. Includes predicted value of inventory investment for the equipment and defense group. Thus sales, orders, and lagged inventory stock of that group are excluded from the respective explanatory variables.

b. Sales measure is consumer expenditures on durable goods.

c. Proportion of firms reporting commitments of sixty days or longer to the National Association of Purchasing Management, scaled by sales.

d. One-quarter proportionate change in price deflator for farm output, scaled by sales.

e. 0.426 is the sum of lagged weights; the successive weights, starting from the current quarter and working back eight quarters, are: $0.010,0.028,0.092,0.074,0.071,0.070,0.046,0.027,0.008$.

f. 1.51 is the sum of lagged weights; working backward from the current quarter, the successive weights are: $1.048,0.454,0.082,-0.070$.

g. -1.88 is the sum of lagged weights: $-1.290,-0.563,-0.106,0.082$. 
is accounted for by erratic quarter-to-quarter movements, without the cumulative cyclical fluctuations that are so apparent in durable goods.

Although it is strictly applicable only to inventories of finished goods, the extension of the buffer stock model to all of the nondurable sector does not appear to cause any major difficulty. In general, the production period is sufficiently short that no distinction is required among inventories by stage of fabrication. Further disaggregation does not improve the overall predictions, perhaps because the distinction between the inventories of finished goods of an intermediate producer and of purchased materials of a final producer introduces a degree of randomness to the stage-offabrication categories.

It does, however, prove useful to go beyond the basic buffer stock model to account for some special characteristics of inventory changes in nondurable goods. Agricultural products, which experience sudden and largely unpredictable changes in supply, are responsible for some of the erratic inventory movements in this sector. Unanticipated variations in short-run supply are necessarily absorbed by the inventory stock. This source of inventory change is taken into consideration by the addition of a variable in the equation for this sector: The quarterly change in the price deflator for farm output is inserted as a measure of changing supply conditions. There is also some evidence that lengthening delivery delays within manufacturing induce firms to hold higher inventory stocks. To account for this, the equation includes a measure of long-term purchase commitments, designated "buying policy," as a proxy for delivery delays. ${ }^{3}$

With these variables included, the statistical results show the expected negative impact of existing stocks and the positive impact of lagged sales on inventory investment. Unlike durable trade, however, the nondurable sector displays a negative relationship between current sales and inventory investment, suggesting that sales surprises dominate, and temporarily push inventories in the opposite direction.

\section{DURABLE MANUFACTURING}

Inventory investment within durable manufacturing differs sharply from that in the other sectors. While it shows a variance nearly three times that

3. The buying policy variable is the level of current shipments (a scale factor) times the percentage of firms reporting purchase commitments of sixty days or longer, from the National Association of Purchasing Management, as reported monthly in Business Conditions Digest. 
of either of the other two sectors, and accounts for a major proportion of the cyclical changes in total inventories, it displays a far greater quarterto-quarter continuity than durable trade and nondurables. In addition, the inventory-sales ratio is not as stable here in the long run as it is in the other sectors.

The major differentiating factor is the magnified role of work-in-process inventories. For example, the higher inventory-sales ratio of durable relative to nondurable manufacturing is almost fully accounted for by the higher level of work-in-process relative to sales-about 0.8 against 0.2 for monthly data. It is also here that the post-1966 rise in the overall ratio of inventories to sales is concentrated.

The greater importance of goods-in-process inventories results from the relatively long period of production for most firms within durable manufacturing. Thus, a substantial proportion of inventory investment is related to the lag between the initial production response to new orders and their final shipment. This is a more passive process than that implied by the buffer stock model in the sense that firms are responding to past orders rather than anticipating future sales.

Firms tend to produce to order rather than to stock where long periods of production are associated with specialized products. The result is that finished goods inventories are of relatively minor importance, and sales forecast errors are not a major source of instability. Purchased materials remain a significant element of variation, but stocks of materials will be more closely related to new orders than to shipments.

The major significance of these distinct characteristics of durable manufacturing is to shift the emphasis in the explanation of inventories from shipments to new orders. That new orders are important to the individual firm does not necessarily imply that they are equally so at the aggregate level. For example, in the extreme case where all final goods are produced to stock and intermediate goods are produced to order, orders would be an important determinant of inventories for intermediate goods producers. But, if these orders merely reflect expected future sales of the finished goods producers, they would simply represent a transmission of sales expectations back up the line. In that event, expected sales would still be the driving force in inventory investment. Even so, the relevant sales forecast would have to be linked to the total length of the production period rather than simply to the current quarter. 


\section{DEFENSE AND BUSINESS EQUIPMENT}

Orders are a particularly important determinant of inventories within the defense and business equipment industries. Both of these finished goods industries are dominated by production to order. For both, production extends over several quarters and orders result in a major impact on income and production, reflected in inventory accumulation, in advance of the actual expenditures. The timing discrepancy between defense expenditures and their impact on the economy has been widely recognized and analyzed. ${ }^{4}$ But the timing effect is not limited to defense goods. It is important for other final products, such as business equipment, that involve a sufficiently long production-to-order process.

Several factors argue in favor of a separate treatment of the defense and equipment group within durable manufacturing. Its inventory-sales ratio is far higher than the average and thus contributes to erratic movements in the aggregate ratio when the output mix shifts between equipment and defense on the one hand and consumer-oriented industries on the other. Second, the inventory-sales ratio of this group is highly variable over periods of several years and is not readily explained in terms of a preferred buffer stock relative to sales. Third, to the extent that they reflect a firm commitment for future final sales, orders, rather than sales, should be stressed as the initial source of stimulus to inventory building in this group.

Separate estimates of inventories of the business equipment and defense industries do not exist on a basis that corresponds with the national income accounts. But an aggregate industry series for shipments, inventories, and new orders is available. ${ }^{5}$ Although it is geared to book values and is not readily converted into constant dollars, this series closely approximates the major movements of the national income accounts data.

Shown in Table 1 is an empirical relationship that explains inventory

4. See, for example, Murray L. Weidenbaum, "The Timing of the Economic Impact of Government Spending," National Tax Journal, Vol. 12 (March 1959), pp. 79-85. The timing adjustment has also been introduced into several econometric models, such as those of the University of Michigan and the Federal Reserve Board-Massachusetts Institute of Technology. This is usually accomplished by introducing next period's change in defense spending as a determinant of current inventory accumulation.

5. U.S. Bureau of the Census, Manufacturers' Shipments, Inventories, and Orders: 1947-63 (revised), Series M3-1 (1963), Table 8, and ... 1961-1968, Series M3-1.1 (1968). 
accumulation in this sector in terms of current sales, the buying policy variable previously used as a measure of delivery delays, and a lag structure on new orders over the previous eight quarters. Inventory accumulation is thus viewed as primarily the result of a timing discrepancy between production and shipments, both of which are related to previously received new orders. The lagged inventory stock does not enter significantly into the equation, nor do current or lagged sales. These results illustrate the sharp difference between inventory behavior in this industry and in the sectors that are oriented more toward production to stock. ${ }^{6}$

The measure of delivery delays is particularly important during the 1966 period when excessive demand pressures and fears of material shortages apparently had a major impact on inventory accumulation. The orders formulation also captures the post-1966 rise in the inventory-sales ratio, for the average of the errors from 1966 to 1969 is essentially zero. An attempt was made to test for shifts in the mix of orders toward items with longer or shorter delivery periods by including aerospace orders separately; but this did not significantly improve the fit. It would appear that a separation of business equipment and defense from the rest of durable manufacturing is sufficient to capture the major effects of variations in the average period of production, and further division is not of crucial importance. Equations similar to that of Table 1 with coefficients of determination above 0.8 were obtained for separate estimates of inventory investment in defense products and in machinery and equipment.

Given these results for the defense and equipment group, one should ideally separate it from the total of durable manufacturing and then explain inventory investment for the other durable industries. But the data do not permit such an approach. As noted above, only book value data are available for inventories of defense and equipment, and these obviously cannot be subtracted from the constant-dollar stocks of total durable manufacturing so as to derive a reliable estimate of inventory investment for the rest of durable manufacturing. It seemed advisable therefore to adopt an unusual approach, focusing on the inventory investment of total durable manufacturing but using as an explanatory variable the predicted values from the inventory equation for the equipment and defense group.

6. The buying policy variable reflects in part the level of sales. But the fact that it is a highly significant explanatory variable does not imply that sales are contributing much to the explanation. As reported in Table 1, sales taken separately have a tiny and statistically insignificant coefficient. 
In doing this, shipments, new orders, and lagged inventory stock of the equipment and defense group - adjusted by the durable manufacturing deflators, for lack of anything better-are excluded from the corresponding independent variables for total durable manufacturing.

Two alternative inventory equations for durable manufacturing are shown in Table 1. Equation (4) essentially follows a buffer stock formulation, except for the special treatment of defense and equipment. The coefficient of 1.8 on the predicted inventory investment of the defense and equipment group presumably reflects a magnified impact of correlated inventory buildups in industries supplying the defense and equipment group. It is striking that the defense and equipment prediction is the most highly significant of all the explanatory variables. The negative impact of existing stocks also comes through far more strongly than the influence of either current or lagged sales.

Equation (5) is more complex in that it includes distributed lags on changes in new orders and on a second variable, constructed by multiplying the capacity utilization rate by the change in new orders. The negative coefficient on the second variable signifies that high utilization reduces the impact of a rise in orders on the inventory-sales ratio. Such an interaction may emerge for various reasons: (1) economies in the use of work-inprocess stocks as the production pipeline fills up; (2) a postponement of the production response to new orders at high utilization of capacity; or (3) a shortening of the production period, with a consequent reduction in the ratio of goods-in-process to shipments as demand pressures increase. ${ }^{7}$

The inclusion of the orders variables brings the coefficient on the prediction for defense and equipment close to unity. With orders to supplying industries explicitly taken into account, the expected investment of the defense and equipment group is simply translated dollar for dollar into the total for durable manufacturing. The use of information on new orders significantly improves the equation, but because of the difficulty of predicting orders, equation (4) may be preferable for forecasting purposes.

The inclusion of orders variables is, of course, not new, but it has usually been accomplished by using levels of, or changes in, unfilled orders rather than the inflow of new orders. In using unfilled orders, previous studies

7. Because current sales are also in the equation and some part of a rise in orders will be reflected in them, the orders coefficients do not measure the total effect of orders on inventories. Also, since the lagged coefficients on the interaction term do not sum to zero, my results are not fully consistent with explanation (2). 
have emphasized precautionary motives for stock building rather than the consequences of the lag between orders and delivery. Once a lag structure for new orders was included in equation (5), no significant results could be found for unfilled orders; the precautionary motive appears to be more accurately measured by the series on purchase commitments in excess of sixty days.

\section{SOME FURTHER RESULTS}

In all of the above equations, experiments were conducted with more elaborate calculations of anticipated sales and price expectations (primarily distributed lags on past changes). A significant relationship never emerged, and the coefficients were only infrequently of the expected signs. Such factors could, however, influence inventories indirectly through the flow of new orders in durable manufacturing. No direct role for monetary variables could be identified. Despite isolated reported instances it is difficult to believe that monetary policy can have a significant direct impact on this demand component. Such measures as the bank loan rate, interest rate differentials, and rates of change of the monetary base were tested-all without success.

Sales forecast errors have been stressed in many studies of inventory behavior. They are particularly important for those theories of the business cycle that look to inventories as a source of endogenous cyclical behavior. Since 1959 the Office of Business Economics has collected at the beginning of each quarter manufacturers' sales and inventory anticipations for the current and following quarters. In a recent study Hirsch and Lovell examined in detail both the accuracy of the anticipations data and their place in the inventory decision. ${ }^{8}$ They found that anticipations were a more accurate predictor of actual sales for individual firms and industry aggregates than previous studies had indicated. On the other hand, sales anticipations appeared to be of only marginal value in explaining actual inventory accumulation.

My results, based on a considerable expansion of the data beyond the eighteen quarters used in the Hirsch and Lovell study, strongly support their conclusions. Reestimation of the aggregate inventory equations they used, together with a variety of alternative equations, suggests that produc-

8. Albert A. Hirsch and Michael C. Lovell, Sales Anticipations and Inventory Behavior (John Wiley \& Sons, 1969). 
tion plans are sufficiently flexible to make sales forecast errors a relatively minor source of disturbance. The sale anticipations were at best of marginal importance. If the "expected sales" of the buffer stock formulation are measured as a weighted average of actual sales and previously reported anticipated sales, the weight attached to the latter was very low-only 0.08 for durables and 0.04 for nondurables.

However, use of the reported anticipations of inventory investment did yield equations nearly as accurate as those of Table 1. The sales forecast errors still played no significant role even in conjunction with the inventory anticipations. These results are consistent with those reported in the previous section, which suggested that inventory changes within durable manufacturing are largely anticipated and result from the structure of the production process. The proper place to search further for aid from sales forecast errors seems to be within the trade sector. In that area, the length of delivery periods may limit the flexibility of stock adjustments to surprises in sales.

\section{Recent Developments}

The current economic slowdown has been marked by a steady and quite smooth decline in the rate of growth in real GNP that began with the imposition of restrictive stabilization policy in the middle of 1968. It has not been accompanied by the violent swings in inventory investment that were so apparent in previous experience. The 1966-67 period provides the most recent illustration of a more active role for inventory investment. Nonfarm inventory accumulation totaled more than $\$ 14$ billion (1958 prices) in 1966 and soared to a peak rate of $\$ 19$ billion in the fourth quarter. In contrast, 1969 was a year of moderate inventory accumulation at a rate less than half that of 1966. In addition, the 1966 increase was associated with a rapid expansion of defense spending. Since a reversal of the war buildup is now underway, it is becoming increasingly important to determine the impact of defense orders on inventory investment.

This section first describes an attempt to isolate several factors that made 1966-67 an abnormal period of inventory accumulation and that distinguish it from the current period. It goes on to an examination of the sources and character of the current slowdown in inventory investment. 
THE 1966-67 EXPERIENCE

In part the difference between 1966 and the current period can be traced to a slower rate of growth of final sales in 1969. But between the end of 1965 and the end of 1966, the accumulation of nonfarm inventories was $\$ 8$ billion in excess of what was required to hold constant the inventory-sales ratios for the three major sectors. In 1969, by contrast, the excess appears to have been a more modest $\$ 1.5$ billion. As Table 2 reveals, the equations do not capture this excess precisely; they understate inventory investment by $\$ 2.2$ billion in 1966 and overstate it by $\$ 0.8$ billion in 1969 . But they do identify several factors that contributed to the abnormal inventory accumulation of 1966.

First, inventory investment was significantly affected by the very high levels of resource utilization throughout 1966. The lengthening of delivery lags on purchased materials led firms voluntarily to increase their inventory stocks relative to sales. The rise during the year of 10 percentage points in the proportion of firms reporting purchasing commitments in excess of sixty days is estimated to have contributed a $\$ 2.2$ billion addition to the inventory stock during the year. In addition, the high utilization rates and substantial backlogs of unfilled orders exerted a stimulative effect on production, and thus on work-in-process inventories, and delayed their response to the slowing in the inflow of new orders that began in the middle of the year.

The rapid expansion of defense and equipment orders in late 1965 and 1966 was the second major influence on inventory investment of that period; it significantly raised the normal inventory-sales relationship within durable manufacturing. Between the third quarter of 1965 and the third quarter of 1966 , new orders in the equipment and defense group increased by 25 percent and exceeded shipments by $\$ 7.6$ billion. As a result, this group of industries made a large contribution to overall inventory accumulation. While the group represented only one quarter of total shipments of durable manufactures, it was directly responsible for nearly half of the $\$ 6.5$ billion rise in durable manufacturing inventories in 1966.

It is doubtful, however, that the 1966 inventory increase in equipment and defense can be attributed exclusively to the lag between production and shipments and the consequent buildup of work-in-process. The buying policy variable contributes $\$ 1.2$ billion to inventory accumulation in defense and equipment during the year.

I have attempted to estimate the contribution of defense alone, as distin- 


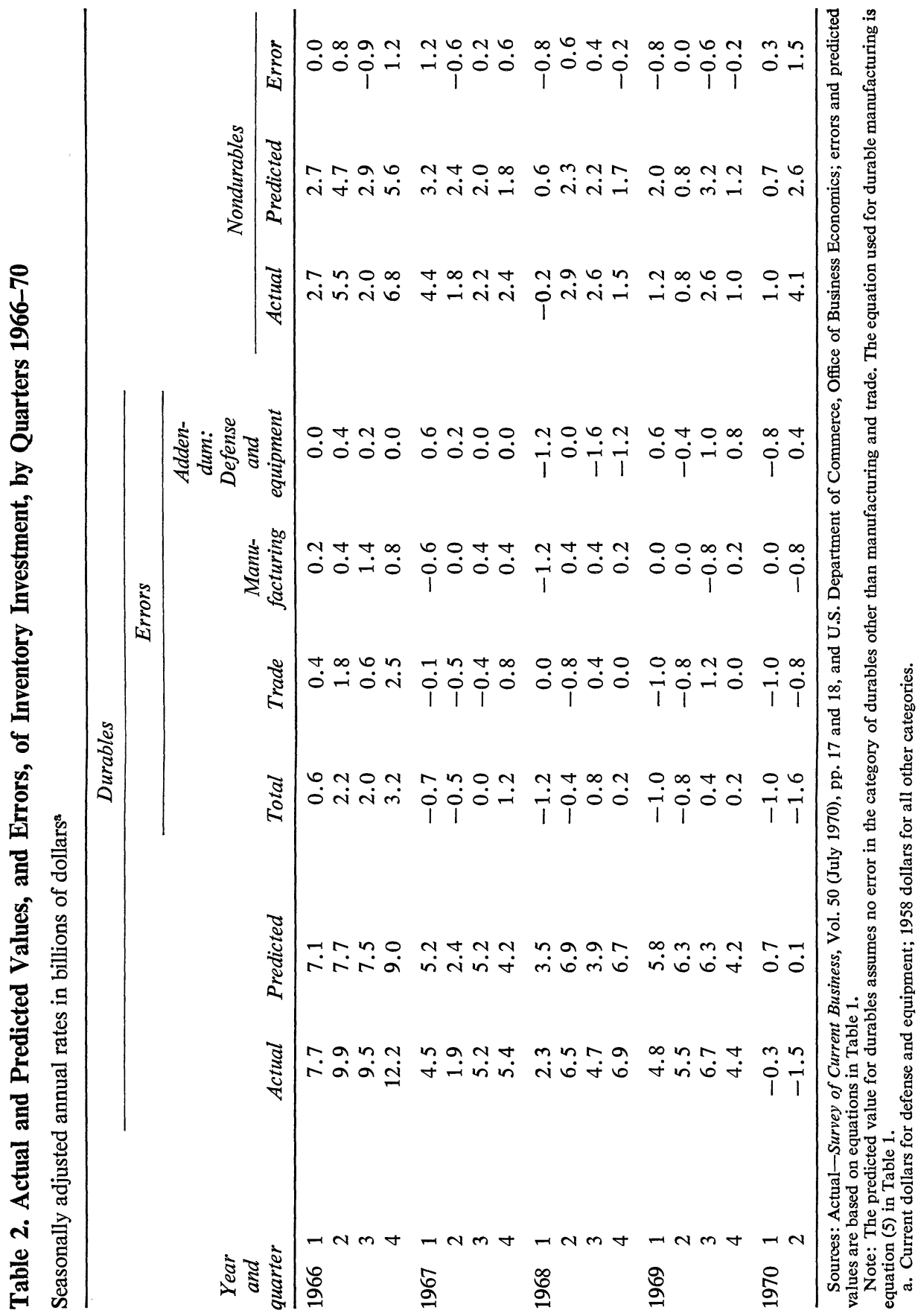


guished from that of defense and equipment combined. Since a separate classification of the defense industry does not exist for the 1966 period, a direct measure is not possible. An indirect estimate of the defense buildup was made by relating the orders of the combined equipment and defense group to military prime contract awards for hard goods, and the shipments series to government purchases of durable goods. Orders and shipments were then reduced to a level consistent with a 2 percent growth in prime contracts and government purchases starting from their actual levels of the first half of 1965. The 2 percent upcreep was intended as a rough allowance for price increases. This provided an estimate of what shipments and orders would have been in the absence of the defense buildup. These estimates in turn were used in equation (3) of Table 1 to calculate what inventory investment of the equipment and defense industries would have been in such a world.

The implied impact of Vietnam war expenditures is shown on a semiannual basis in Table 3 . These estimates are very crude, but they indicate a

Table 3. Inventory Investment of the Equipment and Defense Group and Estimated Impact of the Vietnam Buildup, by Half-Years 1965-70

Annual rates in billions of dollars

\begin{tabular}{clccc}
\hline Year & Total & $\begin{array}{c}\text { Inventory investment by } \\
\text { equipment and defense group }\end{array}$ & \\
\cline { 2 - 3 } and & $\begin{array}{c}\text { Estimated } \\
\text { defense } \\
\text { component }\end{array}$ & $\begin{array}{c}\text { Change in defense } \\
\text { purchases from } \\
\text { preceding period }\end{array}$ \\
\hline 1965 & First & 0.8 & 0.0 & -1.2 \\
& Second & 2.0 & 0.6 & 1.5 \\
1966 & First & 3.0 & 1.5 & 4.3 \\
& Second & 4.0 & 2.0 & 6.2 \\
1967 & First & 3.3 & 2.0 & 6.2 \\
& Second & 2.0 & 1.2 & 2.3 \\
1968 & First & 1.6 & 0.8 & 2.3 \\
& Second & 0.8 & 0.0 & 0.9 \\
1969 & First & 3.2 & 0.5 & -0.5 \\
& Second & 4.1 & -0.2 & -0.5 \\
1970 & First & 0.9 & -1.0 & -1.2 \\
\hline
\end{tabular}

Sources: Inventory investment by equipment and defense group-U.S. Bureau of the Census, Manufacturers' Shipments, Inventories, and Orders: 1961-1968, Series M3-1.1 (1968), and "Current Industrial Reports," Series M3-1 (1969 and 1970), monthly issues; defense component-estimated by author (see text); defense purchases-national income accounts defense purchases, excluding military wages and salaries, computed from data in Survey of Current Business, Vols. 49 and 50 (July 1969 and July 1970, respectively), and unpublished data from U.S. Department of Commerce, Office of Business Economics.

a. The data are shown in current prices because of the lack of a suitable deflator; as a result, the decline of the final two years is understated. 
substantial impact on inventory accumulation in 1966 and 1967. The timing adjustment also shifts into the first two years of this five-year period a larger proportion of the economic impact of the war than is implied by the rise in defense expenditures.

Since they ignore the secondary effects on the inventories and shipments of the material-supplying industries, these estimates understate the full impact of the war buildup. The first equation for durable manufacturing in Table 1 would suggest that the impact on inventory investment of the material-supplying industries can be substantial. On the other hand, a large proportion of the early expenditures were for services and nondurable goods, sectors in which the timing discrepancy is of relatively minor importance.

These estimates of the inventory buildup appear to be significantly smaller than those Galper and Gramlich developed in their study of the lag between prime contract awards and defense expenditures. ${ }^{9} \mathrm{My}$ results imply a shorter average time lag between production and shipment than theirs. In addition, their measure of the inventory accumulation as the difference between production and shipments is conceptually different from the one used here.

The estimates in Table 3 are also somewhat smaller than those provided by the Department of Commerce to Okun and Teeters, which were intended to include secondary effects on supplying industries. ${ }^{10}$

Durable manufacturing was not the only source of the abnormal inventory buildup of 1966. In fact, one of the intriguing aspects of the period is the extent to which an excessive rate of inventory accumulation occurred in every sector. This would suggest that the primary cause was a general economy-wide influence such as tight resource utilization, rather than a specific influence such as the defense buildup.

The 1966 rise in nondurable inventories is explained quite well by a combination of increased precautionary holdings, a sharp curtailment of the rate of growth of final sales, and a substantial drop in farm prices in the fourth quarter. In addition, the rapid growth of final sales in 1965 resulted in a low ratio of inventories to sales at the beginning of 1966.

As Table 2 indicates, I do not have a satisfactory explanation for the rise of durable trade inventories in 1966. The large increases of the second and

9. Harvey Galper and Edward Gramlich, "A Technique for Forecasting Defense Expenditures," Review of Economics and Statistics, Vol. 50 (May 1968), pp. 143-55.

10. Arthur M. Okun and Nancy H. Teeters, "The Full Employment Surplus Revisited," Brookings Papers on Economic Activity (1:1970), p. 89. 
fourth quarters are substantially underestimated by the equation. This sector thus illustrates one of the difficulties of relying on a pure accelerator approach to inventory behavior. The equation is adequate for predicting the typical movements of inventories and even their response to an existing stock-sales disequilibrium. But a delayed response to sales changes does not appear to be a satisfactory explanation for the initial departure from the normal inventory-sales ratio.

An examination of the errors in the equation also reveals that it consistently underestimates the magnitude of the major cyclical swings in durable trade inventories. This may be a problem that stems from using actual sales as a proxy for expected sales, since the equation may be unable to distinguish between erratic short-run sales fluctuations and the more drastic cyclical movements that lead to major inventory adjustments. But I was unable to improve the results with either additional variables or disaggregation. I can report only that the increase in the inventory-sales ratio during 1966 was not limited to any specific category of durable trade and that the ratio returned to a more normal level by the middle of 1967 .

During 1967, the response of inventory investment in durable trade and nondurables to the excesses that existed at the beginning of the period can be viewed as fairly typical by historical standards. For both sectors the inventory-sales ratio had returned to more normal levels by the end of the year, and the errors reported in Table 2 are not particularly large. In durable trade, inventory investment dropped to $\$ 1.2$ billion in the first half of 1967 from the previous year's rate of nearly $\$ 3.0$ billion. Reflecting a slower rate of adjustment, inventory investment in nondurables remained at a high level in the first half of 1967, but fell later in the year.

Inventory investment declined sharply within durable manufacturing after 1966. Nonetheless, the inventory-sales ratio did not return to the level that prevailed before 1966 and inventory investment remained positive throughout 1967. In this sense, the adjustment to the initial excesses was surprisingly mild. The major reason for this behavior was the shift in the composition of output toward the defense and equipment group that continued into 1967. Defense and equipment shipments rose as a proportion of total shipments, reaching 28 percent by the end of 1967. In addition, the buildup of work-in-process within defense and equipment resulted in a rise in the inventory-sales ratio of that group that did not reflect an inventory excess in the usual sense. These two factors together account for over 50 percent of the rise in the overall inventory-sales ratio between 1965 and the end of 1967. Thus they substantially reduce the estimates of the inventory 
excess that actually existed within the period. The separate treatment of equipment and defense within durable manufacturing allows the equation to reflect the 1967 behavior with relatively minor errors.

\section{THE 1969-70 SLOWDOWN}

In contrast to the 1966-67 experience, inventory investment maintained a fairly stable rate throughout 1969. It then adjusted to the decline in final sales in early 1970 without a major change in inventory-sales ratios. To be sure, the rate of inventory accumulation fell by $\$ 5.1$ billion (1958 prices) between 1969 and the first half of 1970-from $\$ 7.2$ billion to $\$ 2.1$ billion. This drop accounted for a major proportion of the decline in output. Unlike 1966-67, and like the previous four periods of recession, 1970 witnessed a decline in real final sales. Yet it is notable that, like 1967 and unlike the previous recessions, inventory investment remained positive in 1970.

I attribute the greater stability of recent inventory investment largely to the reduced role of the special factors that dominated earlier periods. The absence of precautionary influences on inventories, the relative stability in the composition of output in so far as it influenced industries with extensive work-in-process, and the more gradual slowing of final sales all contributed to a smoother inventory adjustment than in 1966-67.

In particular, no major excesses of inventory building developed during 1969. The growth of real final sales shifted gradually downward during much of 1968 and 1969. In the prolonged period of gradual slackening in overall demand, inventories became relatively free of capacity restrictions. The proportion of firms reporting long-term purchasing commitments gradually declined after the end of 1966, and in 1969 reached a level below that of 1965 . Thus during 1969 most of the precautionary inventory buildup of 1966 had been eliminated. With the reduction in utilization rates, inventory investment was not being stimulated by large backlogs when orders turned down in late 1969.

Defense activity slowed substantially, but much of the initial reduction in spending was concentrated in nondurables and services, and therefore it did not have a major inventory impact. In addition, the drop in prime military contracts during 1969 was largely offset by a continued expansion of orders for private equipment. Thus the decline of orders for equipment and defense products was limited to the first half of 1970 and even then did not have a major effect on production or stocks.

The equations are able to track the 1969-70 experience with a fair degree 
of accuracy. However, the durable trade equation again underestimates the magnitude of the cyclical swing in inventory investment. The inventory adjustment in this sector appears to have proceeded at a slightly more rapid rate than that implied by the equation, with a $\$ 2.6$ billion drop in the rate of investment between the second half of 1969 and the first half of 1970. As real final sales of nondurables stalled in the second quarter of 1970, nondurable stocks piled up, but the inventory-sales ratio did not move drastically out of line with historical experience. Only in the second quarter did stocks of durable manufacturers decline; that sector's inventory-sales ratio rose 6 percent above its level of the last half of 1969, with the increase concentrated in work-in-process.

\section{The Outlook}

Will inventory investment be a leading element in the expansion that many experts see on the horizon, as it was in recoveries from the previous four recessions? Two major factors suggest more sluggish behavior: the background of greater stability during the 1969-70 slowdown, and the expected continuation of the decline in defense spending from its Vietnam war peak.

First, the likelihood of a large rebound in inventory investment is reduced by the stability of inventory behavior in the recent past. As described above, stocks did not become excessive to any major degree in 1968-69. And because excesses did not materialize, they did not have to be worked off by liquidation of stocks. Thus inventory investment starts from its positive rate of $\$ 2.1$ billion (1958 prices) in the first half of 1970-in sharp contrast with the negative rates ranging from $\$ 4$ billion to $\$ 6$ billion that marked the last stages of the previous four recessions. Because of the substantially higher base, the prospective upswing of inventory investment is most unlikely to have the dramatic proportions witnessed in past business cycle recoveries.

An additional source of restraint will operate in durable manufacturing, where defense spending will, to a degree, reverse its effect of 1966-67. Defense Department prime contract awards for hard goods have declined 33 percent since the fourth quarter of 1968, with an 18 percent decline in the first half of 1970. Furthermore, any major expansion in private equipment orders that could offset this decline seems rather unlikely. New orders for defense and equipment, which rose 11 percent in 1969, began to reflect some of the scheduled decline of defense activity in a 6 percent drop in the 
first half of 1970 from the second half of 1969. Because of production delays, the impact of the decline in orders on inventories will be concentrated primarily in the latter part of 1970 and in 1971.

On the way down as well as on the way up, the especially high inventorysales ratio of defense and equipment will play a significant role. Reflecting that higher ratio, the rise in shipments of this group from 24 percent to 31 percent of total shipments of durable manufacturing accounts for an addition of about $\$ 2.5$ billion to the total stock in the middle of 1970. If their share should fall back toward its pre-Vietnam level the impact on the overall inventory-sales ratio would not be insignificant. The current drop in defense orders, coupled with an anticipated leveling of private investment, makes some movement in this direction highly probable.

If the existing level of prime contracts is compared with anticipated national defense spending for 1971, it appears that prime contracts in the second quarter of 1970 reflect nearly all of the scheduled reduction. Therefore, on the assumption of a constant level of contract awards in the future, I estimate that the defense component of inventory investment will drop to annual rates of decumulation of $\$ 2$ billion in the last half of 1970 and $\$ 1.5$ billion in the first half of 1971 . Of course, such a reduction would not compare with the extreme inventory decumulation observed in the post-Korean war experience of 1953-54. Total prime contract awards dropped 76 percent between the first quarter of 1953 and the first quarter of 1954. The current decline is of far more moderate proportions. In addition, while most of the reduction in defense stocks is still to come, it appears that inventory investment has largely adjusted to the decline in civilian demand. Thus, the two factors will not be simultaneously depressing inventory accumulation.

Rather, this analysis implies that, assuming no major change in fixed investment, the increase in the inventory stock over the next year will be about $\$ 2$ billion less than proportionate to the rise in final sales. If real final sales should grow as much as 4 percent, inventory investment would have to be $\$ 7$ billion (1958 prices) to keep the stock proportionate to sales. The suggested downward adjustment of $\$ 2$ billion would then point to a $\$ 5$ billion rate of inventory investment. If, however, real final sales should rise only 2 percent, the indicated rate of inventory investment would be only $\$ 1.5$ billion.

All in all, the analysis would suggest that an inventory cycle is not an adequate frame of reference for viewing the present behavior of the economy. Instead of a sharp and severe cycle, there seems to be a slow but steady departure of GNP growth from a full employment path. 


\section{Comments and Discussion}

James Duesenberry: Barry Bosworth is an unusually cheerful inventory investigator. Others who have worked in this field have seemed, at times, to throw up their hands because of the complexities. Yet the fact that Bosworth offers a more encouraging report on the possibilities of explaining inventories may reveal more about writing style and personality than about the actual quantitative results. His own standard errors still leave substantial unexplained variation in inventories, even though, considering the difficulties, the equations look good.

The delivery lag or buying policy variable is an interesting contribution. But I am bothered by the underlying logic of that notion. It seems to say that when capacity utilization goes up, firms have trouble filling orders and a delivery lag appears. This leads the buyers of materials to try to protect themselves by increasing their orders and by making commitments farther ahead in the hope of getting their supplies guaranteed. That in turn stimulates producers of materials to turn out more. Consequently, we end up with more inventory, rather than less, as one might think at first. In the case of a capacity bottleneck, people are trying to buy things that cannot be produced fast enough. That could result in drawing inventories down, particularly at the manufacturing level, just as readily as it could push stocks up. The equations say that delivery lags operate to increase stocks, and the buying policy variable comes through loud and strong in that direction. Perhaps one reason for that effect is that, in a regime of supply difficulties, firms accumulate work in process because they run into delays and can't finish output. A semifinished thing sits there on the floor and gets counted in inventories until some order for materials is filled. 
I'm not proposing to explain how it operates, however. Here is a case where the empirical results are great, but the underlying logic has not been spelled out. I think it would be worthwhile for somebody to work on that.

A second feature of the statistical approach in this paper is the way defense and business equipment are chained up to durable manufacturing as a whole. That appeals to me as an ingenious way of getting around some rather difficult problems. One advantage is that it's probably easier to predict defense and equipment orders, and to analyze the causes of their movements, than it is to predict or explain the change in orders for overall durable manufacturing. The total involves all kinds of changes in orders from one sector of manufacturing to another.

Other economists have previously found some type of orders variable to be very useful in an inventory equation. But then they needed an equation to predict orders, or at least unfilled orders, and often they could not get over this hurdle to complete the system of two separate equations. This aspect of the Bosworth equations has not been tested. In testing this approach, it would be necessary to see how well one could do forecasting defense orders. They have rather long lags, so that one would not have to do too much forecasting to make this work as a complete system. The difficulties of predicting all durable orders suggests that the simpler equation (4) might work out better for forecasting than equation (5), which requires the change-in-orders variables.

Third, as Bosworth points out and as the errors of Table 2 show, 1966 seemed to be influenced by some general bullishness factor that swelled inventory investment in nondurables and durables alike. It is striking that the errors in 1966 were in the same direction, all across the board, even with the buying policy variable included. This raises suspicions that some factor, which is not picked up adequately here, was operating. It points to the need for detective work to find the omitted variable.

One final remark on the equations. The durables trade equation shows a distressing amount of unexplained variation generally and does particularly poorly in 1966 and 1970. I suspect that this may be, in part, because the sales variable isn't always playing the role expected of it. The equation essentially interprets current sales as a predictor of future sales and, therefore, as an indicator of the appropriate level of inventories to meet demand. In durables, particularly in automobiles, there is a strong seasonal element involving new models. Although most of the time current sales 
may properly reflect the strength of the demand, there are obviously some periods when sales are being pushed upward by firms precisely because they want to get rid of inventory and perhaps because demand has been disappointing. Obviously, large sales of that distressed kind-due to suppliers' extra efforts-have a different impact on inventory decisions than large sales that result from active consumer decisions.

Perhaps the durable trade equation needs variables that reflect the annual model pattern more closely than does a seasonal adjustment of the industry. It is also necessary to take into account the fact that equations like those dealing with automobile sales have errors with high serial correlation. People who sell these things know these correlations in the errors from experience. Their expectations reflect the continuity, so that when things are sour they expect them to stay sour. The combination of those two features-the model year aspect of products and the considerable continuity in strength of demand-may require a different kind of inventory equation for durable trade inventories than is offered in this paper.

Finally, I want to comment on the forecasting message. Barry Bosworth is telling us that nothing exciting is likely to happen to inventoriesneither a reduction nor any big bounce back from the currently low rates of accumulation. I think that basic message makes sense. It might be worthwhile to get a little perspective by making a slightly different comparison of the 1966-67 episode with 1969-70. I want to emphasize that there was a very substantial swing in inventory investment from the last half of 1969 to the first half of 1970 . In the case of durables, it was nearly as large as the swing from the second half of 1966 to the first half of 1967$\$ 6.5$ billion compared with $\$ 7.5$ billion. The periods seem so different for several reasons. First, nondurables reinforced the downward movement to a greater extent in 1966-67. Second, there was a very sharp peak in the fourth quarter of 1966 and then a steep drop to the bottom in the second quarter of 1967. The timing was not nearly so concentrated in 1969-70.

On the rebound in 1967, only a very modest lift came from inventory investment. The rate in durables was $\$ 3.2$ billion in the first half of 1967 and $\$ 5.3$ billion in the second half. The contribution was only a couple of billion dollars in that category. Nondurables were very little changed. Thus, late in 1967, in the face of rapidly expanding final sales and a continuing (if slightly diminishing) positive impact from defense, there was only a modest upswing in the rate of inventory investment. For the second half of 1970, even less of a lift is probable. Final sales are expected to in- 
crease less in the second half of 1970 than in the second half of 1967. Defense orders are declining and pushing downward. All of this suggests that the movement of inventory investment is not going to be a major factor in either direction.

Arthur M. Okun: One of the interesting features of this paper is its finding on where disaggregation pays and where lumping together is acceptable and even desirable. The results are not necessarily what one might intuitively expect. For example, it is not clear why combining nondurable manufacturing and trade is satisfactory. Bosworth points out that shipments by nondurable manufacturers to merchants in nondurable trade simply shift the holding of inventories initially. To the extent that there is a statistical problem involving either double-counting or failing to count stocks that are in transit, aggregating the two categories can't improve matters. To the extent that there is an important random element as to when shipments take place from manufacturers to retailers, the data could be accurate, but might still be subject to large disturbances depending on just what happened on the last day of the quarter. In that case, one might encounter offsetting errors in trying to explain trade and manufacturing separately and might reduce the errors by combining them.

In a sense, if combined estimates work out well, their success suggests that the official data are really capturing the facts properly, and that perhaps the statistical problem of "float," or in-transit stocks, is not terribly serious.

It is also striking that disaggregating by stage of fabrication did not help. There are good analytical reasons to believe it might, but it did not. On the other hand, it pays to separate business equipment and defense from the rest of durable manufacturing. Moreover, combining equipment and defense is a special kind of aggregation that seems to be acceptable. Presumably this works because these two industries have the same characteristics of production to order and of substantial lags in the production process. The nature of demand is entirely different for the defense industry and for the business equipment industry.

One recurring theme of the paper is the major significance of the difference between production to order and production to stock. This raises other interesting and thought-provoking issues. First, it is dangerous to assume that production to order and long lags in the production process necessarily go together. To be sure, both will appear in the case of ex- 
pensive, highly specialized products. But fruit growers have long lags and yet produce to stock. And good short-order cooks produce to order with short lags. It may be important to distinguish these two forces in inventory models.

Second, where there is both a long production process and production to order, firms might be expected to be able to predict their shipments accurately over a significant time horizon. Basically, their shipments for some months ahead ought to be determined by what is in the pipelineby supply considerations rather than any developments in demand. I do not think the data show that such firms are especially accurate in their sales forecasts. Maybe the supply considerations are hard to predict. Maybe such firms are not terribly interested in near-term shipments and do not make much effort to forecast them accurately.

The paper also has several interesting results on what variables work and where they work. It is striking that the equations imply that nondurables are the only sector in which, on the basis of quarterly data, a rise in current sales means a significant decline in inventory investment. It is the only place where surprises in sales push inventories in the opposite direction for as long as a quarter. In durable trade and durable manufacturing, the higher the current quarter's sales, the higher the current quarter's inventories are expected to be, according to these equations. That doesn't leave much scope for involuntary accumulation or liquidation of stocks.

The results on the buying policy variable are resounding. I will be paying more attention to that series as a leading indicator, in light of these findings. I am puzzled, however, by the fact that it works for business equipment and defense and not for the rest of durable manufacturing. Could that throw any light on the questions James Duesenberry raised about the possible negative-as well as positive-impacts of delivery lags on stocks?

In the review of recent experience, the paper reveals what a heroic role nondurable stocks have played in 1969-70. In the 1966-67 period, the downswing in the nondurable accumulation rate was $\$ 5$ billion. In the current period, the nondurable rate actually rose $\$ 1.5$ billion, from $\$ 2.6$ billion in the third quarter of 1969 to $\$ 4.1$ billion in the second quarter of 1970. It was never down more than $\$ 1.6$ billion during this period. It is a most unusual candidate to be cast as a hero in stabilizing the economy.

In viewing the upswing, the biggest contrast between the present situation and the past is not with the 1967-68 period but rather with 1960-61 
or 1957-58. In those episodes, inventory investment started from a sizable negative rate-especially sizable when viewed as a percentage of the lower GNP of those ancient times. As Bosworth emphasizes, a cyclical recovery model in terms of 1957-58 and 1960-61 would be way off base as a guide to the present inventory outlook.

Barry Bosworth: I did not mean to imply that disaggregating by stage of fabrication failed to yield results. I did experiment with disaggregating in this manner. I found drastically different behavior for goods in process in durable manufacturing than for finished goods or purchased materials. For the latter two, a buffer stock approach seemed to work well. I chose the separation of equipment and defense over the disaggregation by stage of fabrication merely because I thought that orders for defense and equipment were more tractable than orders for total durable goods manufacturing. I did reach negative conclusions on disaggregation of nondurable manufacturing by stage of fabrication, and so have other studies that explored this approach.

\section{General Discussion}

R. A. Gordon asked whether price expectations could have influenced the recent pattern of inventory investment. If price expectations had been unimportant for most of the period to which the equations were fitted, they might not show up significantly in them, and yet might have had a particular effect in this most recent experience.

Bosworth replied that he had experimented some with price expectations, but did not get positive results. He agreed that, if price effects are important, their influence should have been evident in 1969. But 1969 was one of the periods when the equations seemed to be working especially well. This suggests that 1969 inventory accumulation was not affected in any major way by price expectations.

Lawrence Krause asked whether the buying policy variable might not actually be acting as a proxy for price anticipations. Bosworth replied that the movements of the buying policy variable over time were not consistent with such a proxy role. It reached a peak early in 1955, before prices started rising, and then gradually declined all the way to the 1958 recession. 
The same thing happened in 1966-69; it peaked early and then fell by onefourth, returning to its 1964 level.

Alan Greenspan supported Bosworth's interpretation of the buying policy variable. He suggested that the lengthening of commitments and stock building can be observed in the steel industry. Greenspan noted that a lengthening of commitments by purchasers might reflect their judgment that they needed to get on the books sooner in order to get delivery on time. In that sense, the variable might measure supplier's policy as much as buyer's policy.

A number of questions focused on the nature and treatment of inventory data. Gardner Ackley asked whether anyone had tried to forecast the national accounts measure of inventory change in two stages, first predicting book value and then predicting the inventory valuation adjustment of the national income accounts. Bosworth said that it appeared possible to explain the national accounts measure (that is, the figure adjusted for inventory valuation) about as accurately in a single step as one could explain book values. George Jaszi suggested that the erratic movement of auto dealers' stocks made these a likely candidate for separate treatment from other durable trade stocks; but Bosworth reported that his efforts to disaggregate in this way had not yielded improved results. Alan Greenspan suggested that the financial data on trade credit "float" might be investigated for possible clues on the magnitude and movement of in-transit inventories.

Most of the participants in the discussion seemed to share Bosworth's general appraisal of a sluggish near-term outlook for inventory investment. William Fellner, however, noted that inventory-sales ratios have tended to be higher in the early stages of past cyclical recoveries than they are at the present time. He wondered whether this might not offset, in part, some of the other factors tending to restrain the inventory rebound in the current situation. Alan Greenspan suggested that the differences in inventory-sales ratios between the present and previous upturns may not be very significant. Price inflation, which affects sales more fully than it affects the book value of stocks, tends to lower the current statistics on inventory-sales ratios, as compared with earlier periods. 